\title{
Vertical transmission of gill-associated virus (GAV) in the black tiger prawn Penaeus monodon
}

\author{
Jeff A. Cowley ${ }^{1, *}$, Michael R. Hall ${ }^{2}$, Lee C. Cadogan ${ }^{1}$, Kirsten M. Spann ${ }^{1}$, \\ Peter J. Walker ${ }^{1}$ \\ ${ }^{1}$ Cooperative Research Centre for Aquaculture, CSIRO Livestock Industries, 120 Meiers Road, Indooroopilly, \\ Queensland 4068, Australia \\ ${ }^{2}$ Australian Institute of Marine Science, PMB 3, Townsville, Queensland 4810, Australia
}

\begin{abstract}
Chronic gill-associated virus (GAV) infection is endemic in Penaeus monodon broodstock captured from north-east Queensland in Australia and in farmed shrimp produced from these. We investigated the role of vertical transmission in perpetuating the high prevalence of these chronic GAV infections. Reverse transcription (RT)-nested PCR detected GAV in spermatophores and mature ovarian tissue from broodstock and in fertilized eggs and nauplii spawned from wild-fertilized females. In laboratory-reared P. monodon (>12 mo old) that had a high mortality rate, RT-nested PCR detected GAV in male spermatophores at levels significantly higher than that detected in the lymphoid organ. By transmission electron microscopy (TEM), GAV virions were detected in spermatophore seminal fluid, but not sperm cells. Histological evidence of hypertrophied cell foci (spheroids) and TEM observation of GAV nucleocapsids and virions in spheroid cells was also found in $100 \%$ of lymphoid organs of $\sim 1.2 \mathrm{~g}$ juvenile $P$. monodon reared in the laboratory from postlarvae collected from commercial hatcheries. Sequence analysis of PCR amplicons from parental P. monodon and fertilized eggs of artificially inseminated broodstock indicated that GAV associated with eggs can originate from both the male and female parents. Although the female GAV genotype was predominant in eggs, there was some dependence on infection levels in the male and female shrimp as indicated by RT-PCR. RT-nested PCR data on GAV levels in eggs, nauplii, protozoea and PL5 progeny of the artificial matings suggests that vertically transmitted virus is most probably associated with the egg surface.
\end{abstract}

KEY WORDS: Yellow head virus (YHV) · Gill-associated virus (GAV) · Penaeus monodon · RT-PCR · Penaeid shrimp · Prawn · Vertical transmission

\section{INTRODUCTION}

Gill-associated virus (GAV) is a single-stranded (+) RNA virus that has been associated with mortalities in farmed Penaeus monodon in Queensland, Australia (Spann et al. 1997, Cowley et al. 2000a). GAV sourced from disease outbreaks is highly pathogenic and mortalities occur following experimental infection of $P$. monodon and other shrimp species ( $P$. esculentus, Fenneropenaeus merguiensis and Mapsupenaeus ja-

*E-mail: jeff.cowley@csiro.au ponicus) farmed commercially in Australia (Spann et al. 1997, 2000). Diseased P. monodon become lethargic, cease feeding, display reddening of the body and appendages, and extensive cellular necrosis and structural degeneration occurs in the lymphoid organ (Spann et al. 1997). Disease is also accompanied by the appearance of large numbers of helical nucleocapsids and rod-shaped enveloped virions in the lymphoid organ and gill cells. Morphologically, GAV is indistinguishable from yellow head virus (YHV), which is a major pathogen in south-east Asia. GAV and YHV induce similar cytopathology (Boonyaratpalin et al. 
1993, Chantanachookin et al. 1993, Wongteerasupaya et al. 1995, Spann et al. 1997, Wang \& Chang 2000), and sequence comparisons indicate that they represent closely related but distinct genotypes (Cowley et al. 1999).

Asymptomatic chronic GAV infections are restricted primarily to partitioned regions of hypertrophied cells, or 'spheroids', in the lymphoid organ, and were first described as lymphoid organ virus (LOV) infections in healthy Penaeus monodon in Queensland in 1993 (Spann et al. 1995). Sequence comparisons indicate that GAV and LOV are the same virus and RT-nested PCR screening has indicated that the prevalence of chronic GAV infection approaches $100 \%$ in P. monodon broodstock captured from north-east Queensland (Cowley et al. 2000b, Walker et al. 2001). A high prevalence of GAV infection has also been detected in postlarvae produced from these broodstock, which currently supply the majority of the black tiger shrimp aquaculture industry of eastern Australia.

In this paper, we present biological and molecular evidence indicating that vertical transmission of GAV contributes to the high prevalence of chronic infections in wild and farmed Penaeus monodon in eastern Australia. RT-nested PCR was used to detect GAV in eggs and nauplii from wild-fertilized broodstock as well as in spermatophore and mature ovarian tissues. GAV was also detected by RT-nested PCR in postlarvae, and biological evidence of infection in progeny was obtained by laboratory rearing of postlarvae to a size that allowed examination of the lymphoid organ by histology and transmission electron microscopy (TEM). Sequence comparisons of PCR amplicons from the parents and progeny of artificial matings of $P$. monodon from different locations indicated that GAV associated with eggs can originate from both the male and female and that the relative contribution of virus may depend on the infection level in each parent.

\section{MATERIALS AND METHODS}

Source of Penaeus monodon. All P. monodon broodstock used in this study originated from coastal waters in the vicinity of Cairns $\left(16.7^{\circ} \mathrm{S}\right)$, Innisfail $\left(17.5^{\circ} \mathrm{S}\right)$, Ingham $\left(18.5^{\circ} \mathrm{S}\right)$ and Townsville $\left(19.3^{\circ} \mathrm{S}\right)$. These sites span a $400 \mathrm{~km}$ stretch of the coastline in north-east Queensland. Broodstock were obtained directly from commercial trawler operators and post-spawned broodstock were obtained from hatcheries supplied with shrimp from this region. Postlarval progeny of these broodstock were also obtained from hatcheries. In some cases, wild-fertilized females spawned on the night of arrival at a research hatchery at the Australian Institute of Marine Science (AIMS), Cape Ferguson, north- east Queensland (see 'Results'). Eggs and nauplii from these 'wild spawnings' were collected and stored at $-70^{\circ} \mathrm{C}$. Tissue samples were also collected from moribund male $P$. monodon ( $>12$ mo old) that had been reared in tanks at AIMS as part of a domestication project and in which regular mortalities were common. All shrimp tissue samples in addition to eggs, larvae and postlarvae were collected using sterilized equipment, snap-frozen on dry ice or in liquid nitrogen, and stored at $-70^{\circ} \mathrm{C}$.

Broodstock and juvenile Penaeus monodon examined by histology and TEM. In August and December 1993, 3 post-spawned $P$. monodon broodstock (1 male and 2 females) were collected from a hatchery in south-east Queensland. Male (2) and female (10) broodstock were collected in April 1994, and male (1) and female (2) broodstock were collected in November 1994 from the same hatchery. Hatchery records indicated that all broodstock were captured near Cairns or Innisfail. Cephalothoraxes of all 21 broodstock were processed for histology, and portions of lymphoid organ, gill, hepatopancreas, epidermis, nerve cord, gonads and haematopoietic tissue were processed for TEM as described previously (Spann et al. 1995, 1997).

To obtain direct evidence that Penaeus monodon postlarvae (PL) acquire GAV infection in hatcheries rather than subsequently in grow-out ponds, batches of 10000 PL6 and 10000 PL20 were collected from a commercial hatchery in October 1994 and reared in an aquaculture laboratory until they weighed $\sim 1.2 \mathrm{~g}$. At this weight, lymphoid organs could be identified by light microscopy and 100 juveniles were processed for histology. The lymphoid organ and gill tissues of 20 of these were also processed for TEM.

Artificial matings of broodstock and larval rearing. Wild male and female Penaeus monodon broodstock were captured between May and June 1999 and tagged for identification purposes. Shrimp were maintained at AIMS in 10000 l, $4.5 \mathrm{~m}$ diameter indoor sea water tanks with a water depth of $0.85 \mathrm{~m}$ and using a constant photoperiod of 14:10 h light:dark. Tanks had more than $100 \%$ water exchange per day. Incoming near-shore water was settled for $24 \mathrm{~h}$, passed through a $5 \mu \mathrm{m}$ filter, and sanitized using an ozone-treated foam fractionator followed by a $254 \mathrm{~nm}$ UV sterilizer (YooVee, Model CRS1) with a throughput of 100001 $\mathrm{h}^{-1}$. Water temperature ranged between 26.0 and $29.5^{\circ} \mathrm{C}$, salinity between 29 and 35 ppt and $\mathrm{pH}$ between 8.1 and 8.5. Broodstock were fed daily ad libitum a combination of squid, mussels and a maturation diet free of any crustacean material. Two days after molting, females were unilaterally eyestalk-ablated and artificially inseminated. Matings were carried out with males and females from different geographic locations. Both spermatophores were extracted from 
males; one was used for insemination and the other stored for subsequent analysis. Females were monitored daily for ovarian development and, when scored as immediate pre-spawning, were transferred to individual spawning tanks. Spawning tanks and the hatchery system were organized so that eggs and nauplii from individual females could be collected free of contamination from other shrimp in the hatchery. After each spawning, all tanks and equipment were sterilized by treatment with chlorine.

Sub-samples of eggs and nauplii were collected, snap-frozen in liquid nitrogen and stored at $-70^{\circ} \mathrm{C}$. Larvae from each spawning were maintained in triplicate isolated tanks and fed a commercial larval microencapsulated diet. Sub-samples of the different larval and postlarval life stages were collected and stored as for eggs and nauplii.

Males from which spermatophores had been removed and post-spawned females were killed by heart puncture and severing of the ventral nerve cord. Using sterilized surgical equipment, portions of lymphoid organ, hepatopancreas and gill were sampled from males and females. Testes and spermatophores were also sampled from males, as were portions of ovaries and the contents of the thylecum (putative spermatophore and oviduct secretions) from females.

Light and transmission electron microscopy. Histological examinations of shrimp cephalothorax tissues fixed in Davidson's fixative were conducted as described previously (Spann et al. 1995, 1997). Shrimp tissues were also fixed in modified Karnovsky's reagent and processed for TEM to identify GAV nucleocapsids and virions (Spann et al. 1995, 1997).

RNA isolation. Total RNA was isolated from broodstock tissues, eggs and other early life stages by homogenization in TRIzol ${ }^{\mathrm{TM}}$ reagent (Life Technologies) using a pellet pestle and subsequent processing according to the manufacturer's instructions. An additional centrifugation step was used to remove polysaccharide from cuticle-rich samples such as eggs, nauplii, protozoea and postlarvae. Total RNA was resuspended in $25 \mu \mathrm{l}$ diethylpyrocarbonate (DEPC)treated water, quantified by spectrophotometry $\left(A_{260 \mathrm{~nm}}\right)$ and stored at $-70^{\circ} \mathrm{C}$. All reagents and tissue samples were handled in a laminar-flow cabinet in a separate laboratory using aerosol-resistant barrier pipette tips to prevent contamination with PCR products.

PCR primers. RT-nested PCR primers GAV5, GAV6, GAV1 and GAV2 targeting a region of the GAV ORF1b gene have been described elsewhere (Cowley et al. 1999, 2000b). The sequences of PCR and nested PCR primers targeting an alternative GAV coding sequence downstream of the ORF1b gene are GAV69 (5'-TCATATTACTCGCTGTGATCCAGG-3'), GAV121 (5'-TACATAACTAGTTGTGACCGG-3'), GAV175 (5'CTGGTGATCCAGGTTCTTTACA-3') and GAV176 (5'-GATAGCCTTCGATGTTAAGTC-3'). RT-PCR with the primer pair GAV69/GAV121 was designed to amplify a $633 \mathrm{bp}$ product and nested PCR with the primer pair GAV175/GAV176 a 597 bp internal portion of this product. Primers were either synthesized using a Beckman Model 1000 Oligonucleotide Synthesizer or purchased from GeneWorks, South Australia.

RT-nested PCR. RT-nested PCR to detect GAV RNA was performed as described previously (Cowley et al. $2000 \mathrm{~b}$ ) with minor modifications. Briefly, 0.1 or $1.0 \mu \mathrm{g}$ total RNA was denatured in the presence of $35 \mathrm{pmol}$ of each primer (GAV5 and GAV6) by heating at $70^{\circ} \mathrm{C}$ for 10 min followed by quenching on ice. cDNA was synthesized by the addition of $2 \mu$ l Superscript II buffer $\times$ 5, $1 \mu \mathrm{l} 100 \mathrm{mM}$ DTT, $0.5 \mu \mathrm{l} 10 \mathrm{mM}$ dNTP mix, and 100 U Superscript II reverse transcriptase (Life Technologies) in a $10 \mu \mathrm{l}$ final volume. The reaction was incubated at $42^{\circ} \mathrm{C}$ for $1 \mathrm{~h}$, heated at $70^{\circ} \mathrm{C}$ for $15 \mathrm{~min}$ and quenched on ice. cDNA (1 $\mu$ l) was amplified by PCR using Primers GAV5 and GAV6, Taq polymerase (Promega) and 30 cycles of $95^{\circ} \mathrm{C} / 30 \mathrm{~s}, 58^{\circ} \mathrm{C} / 30 \mathrm{~s}$, $72^{\circ} \mathrm{C} / 45 \mathrm{~s}$ followed by $72^{\circ} \mathrm{C} / 10 \mathrm{~min}$ final incubation using reaction conditions described previously (Cowley et al. 2000b). For nested PCR, 0.5 or $5.0 \mu \mathrm{l}$ of the primary PCR was amplified as above using Primers GAV1 and GAV2 and 25 cycles of $95^{\circ} \mathrm{C} / 30 \mathrm{~s}, 58^{\circ} \mathrm{C} / 30 \mathrm{~s}$, $72^{\circ} \mathrm{C} / 30 \mathrm{~s}$ followed by $72^{\circ} \mathrm{C} / 10 \mathrm{~min}$ final incubation. RT-PCR (618 bp) and nested PCR (317 bp) products $(10 \mu \mathrm{l})$ were resolved in $2 \%$ agarose-TAE gels containing $0.5 \mu \mathrm{g} \mathrm{ml}^{-1}$ ethidium bromide. RNA and all PCR reagents were handled in a laminar-flow cabinet using aerosol-resistant tips to avoid contamination.

The alternative GAV RT-PCR using primer pair GAV69/GAV121 (633 bp product) and followed by nested PCR using primer pair GAV175/GAV176 (597 bp product) were performed as described above except that an annealing temperature of $55^{\circ} \mathrm{C}$ and 35 cycles were used for both the primary and nested PCRs.

Sequence analysis. For automated sequencing, PCR and nested PCR products were purified using QIAquick (Qiagen) columns and sequenced directly in both directions using appropriate primers (i.e. GAV5, GAV6, GAV1，GAV2，GAV69，GAV121，GAV175, GAV176), Big Dye ${ }^{\mathrm{TM}}$ dye-terminator reagent (Applied Biosystems Inc., ABI) and Model-377 sequencing systems (ABI) at the Australian Genome Research Facility, Queensland. Sequence chromatograms were analyzed using SeqEd 1.0.3 (ABI), and sequences were aligned using MacVector 7.0 (Oxford Molecular). 


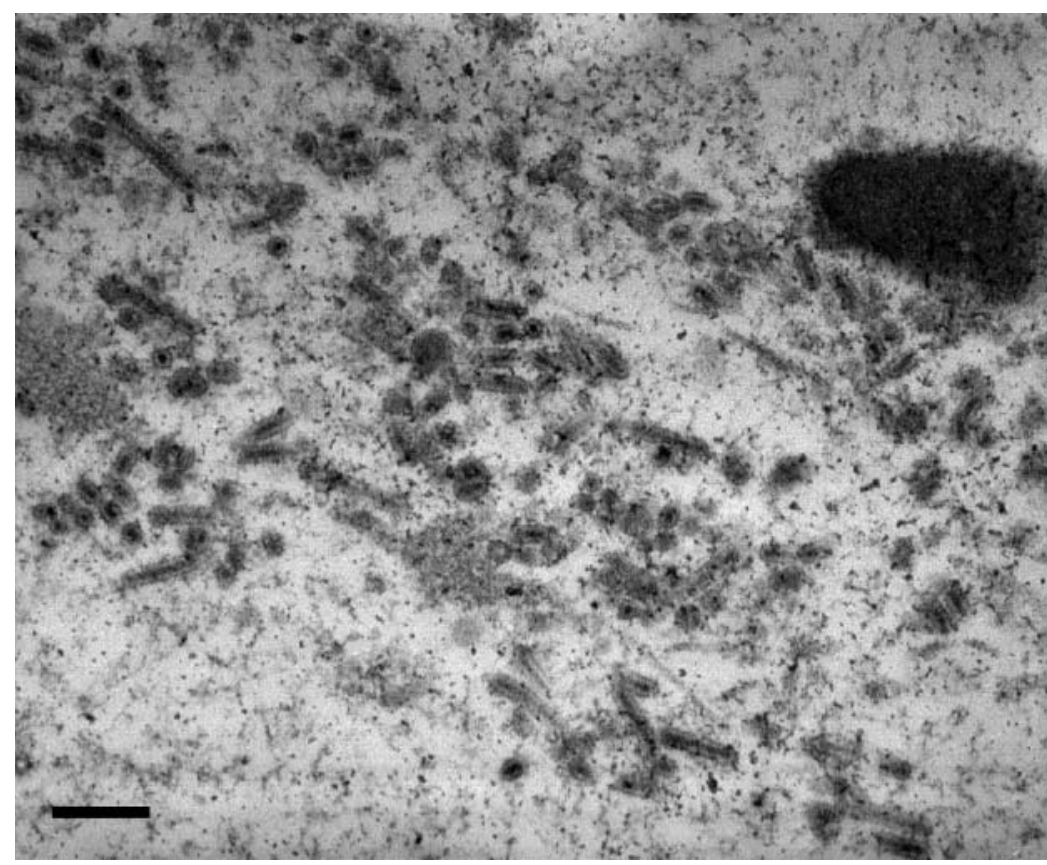

Fig. 1. Penaeus monodon. TEM of GAV virions within seminal fluid of spermatophore of a laboratory-reared shrimp. Scale bar $=200 \mathrm{~nm}$

\section{RESULTS}

\section{TEM identification of GAV in broodstock and juvenile Penaeus monodon}

Healthy male (5) and female (16) Penaeus monodon broodstock from north-east Queensland were obtained from a hatchery subsequent to spawning and cephalothorax tissues were screened for histological and TEM evidence of asymptomatic GAV infection. Hypertrophied cell foci (spheroid bodies) described previously (Spann et al. 1995) were identified in the lymphoid organs of all 21 broodstock (data not shown). By TEM, characteristic GAV nucleocapsids and virions were identified in the cytoplasm of spheroid body cells in all broodstock examined. Unlike previous observations in healthy juvenile and sub-adult shrimp (Spann et al. 1995, Spann 1997), GAV nucleocapsids and enveloped virions, typically loosely arranged, were observed in gill cells of these broodstock. However, their relative numbers were lower than observed in gill tissue of diseased shrimp, and there were no large arrays of virions within cytoplasmic vesicles (data not shown). There was no TEM evidence of GAV infection in the gonads, hepatopancreas, nerve cord, haematopoietic tissues or epidermis of the broodstock.

Spermatophores of 3 of 4 moribund Penaeus monodon broodstock ( $>12$ mo old) from a batch reared in captivity and that were experiencing abnormally high mortalities (see below) were also examined by TEM.
Scattered GAV virions were observed in the seminal fluid of 1 of the 3 spermatophores examined (Fig. 1). In no case were nucleocapsids or virions indicative of GAV replication observed inside sperm cells.

Lymphoid organs of larval and postlarval shrimp are insufficiently developed for ready examination for histopathology or by TEM. Therefore, lymphoid organs of 100, 1.2 g Penaeus monodon reared in the laboratory from hatchery PL6 and PL20 stocks were examined by light microscopy. All 100 juvenile shrimp examined possessed lymphoid organ spheroids characteristic of those described in sub-adult $P$. monodon (Spann et al. 1995) and which comprised between 50 and $90 \%$ of the organ (data not shown). Moreover, lymphoid organs from 20 of these juvenile shrimp selected randomly for TEM all contained characteristic GAV nucleocapsids and enveloped virions (Spann et al. 1995, 1997). There was no TEM evidence of GAV particles in gill cells of these 20 shrimp.

\section{Detection of GAV in broodstock reproductive tissues by RT-nested PCR}

Spermatophores from 4 male Penaeus monodon broodstock sourced from each of the Cairns, Innisfail and Townsville regions of north-east Queensland were tested for GAV using RT-nested PCR. Although no GAV-specific first-step PCR products were amplified from any of the 12 spermatophores examined, all produced nested PCR products (317 bp) indicating the presence of low levels of GAV (Fig. 2).

RT-nested PCR was also used to detect GAV in spermatophores, ovarian tissue and lymphoid organs collected from 4 male and 6 female Penaeus monodon broodstock from a batch reared in captivity for $>12$ mo. The broodstock represented progeny of shrimp sourced from north-east Queensland and were experiencing regular mortalities. The relative RT-PCR and nested PCR product yields for various tissues are shown in Table 1. A GAV RT-PCR (618 bp) product was amplified from lymphoid organ RNA of only 1 male and 1 female shrimp. However, the lymphoid organs of 3 of 4 males and 5 of 6 females were clearly GAV-positive (317 bp product) following nested PCR. All 4 spermatophore RNA samples generated high yields of the primary RT-PCR product compared to that amplified 


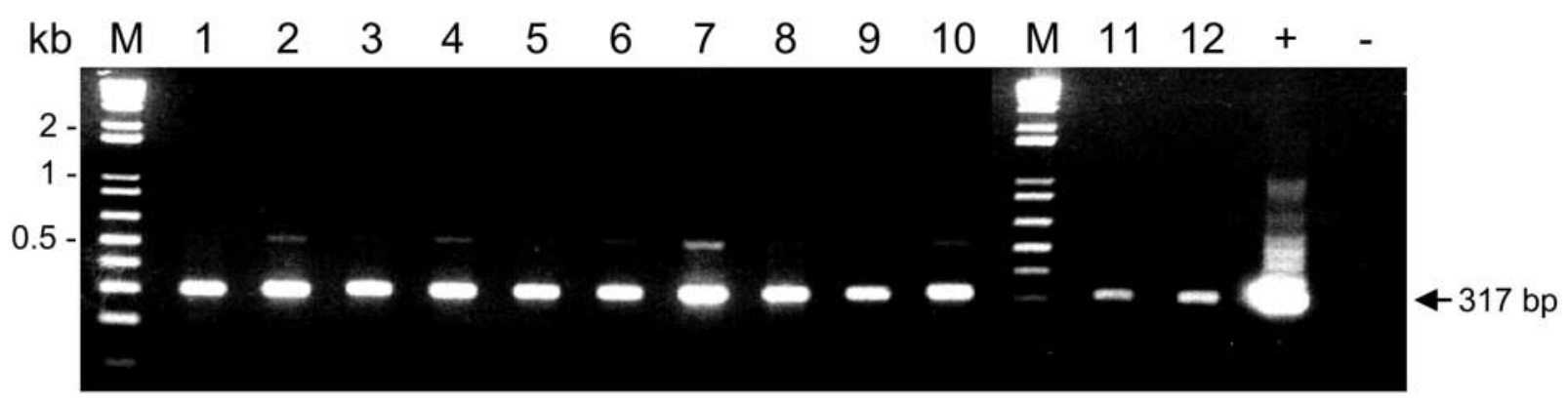

Fig. 2. Penaeus monodon. RT-nested PCR amplification of GAV RNA in spermatophores from 12 healthy wild shrimp collected from Innisfail (Lanes 1 to 4), Cairns (Lanes 5 to 8) and Townsville (Lanes 9 to 12). Total RNA of lymphoid organ from healthy Mapsupenaeus japonicus (-) and P. monodon infected experimentally with GAV (+) were used as negative and positive controls, respectively. cDNA prepared from $10 \mathrm{ng}$ total RNA was used for PCR and $0.5 \mu \mathrm{l}$ of the PCR was used in the nested PCR. The $317 \mathrm{bp}$ nested PCR products amplified with the primer pair GAV1/GAV2 were resolved in a $2 \%$ agarose-TAE gel containing $0.5 \mu \mathrm{g} \mathrm{ml}^{-1}$ ethidium bromide. $\mathrm{M}=1 \mathrm{~kb}$ DNA ladder (Life Technologies)

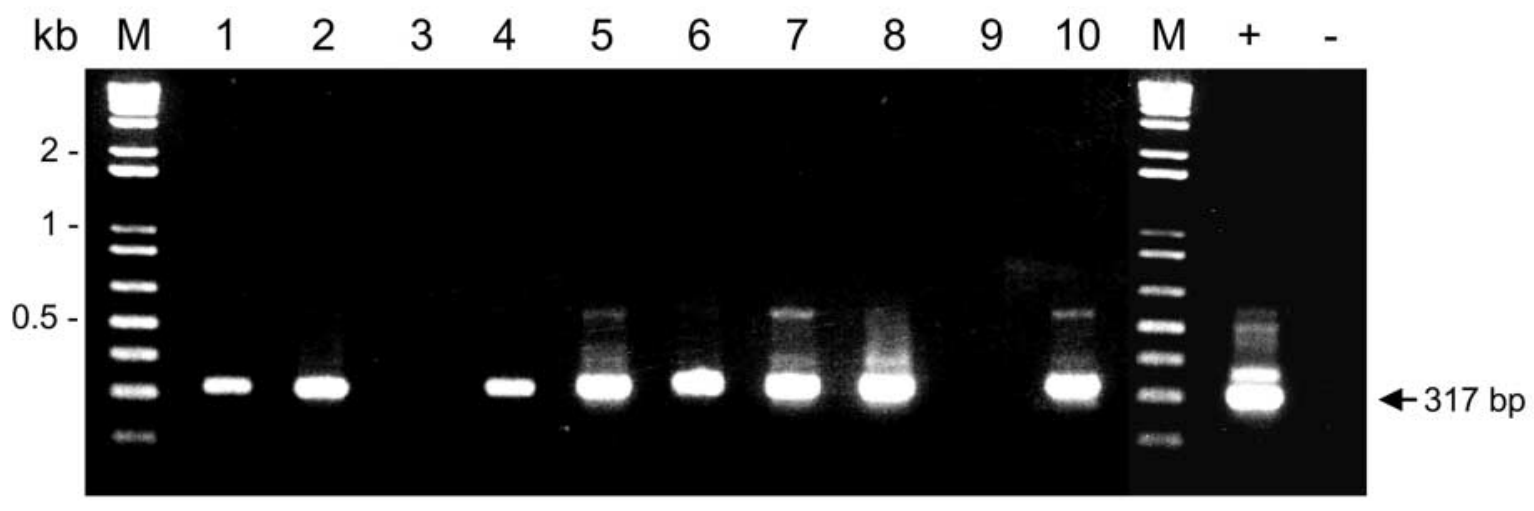

Fig. 3. Penaeus monodon. RT-nested PCR amplification of GAV associated with nauplii (Lanes 1, 3, 5, 7, 9) and eggs (Lanes 2, 4, $6,8,10)$ from spawnings of 5 wild-fertilized females. PCR conditions, GAV negative (-) and positive (+) control RNAs and the gel system for resolving nested PCR products as in Fig. 2. $\mathrm{M}=1 \mathrm{~kb}$ DNA ladder

using an equivalent amount of lymphoid organ RNA from the same shrimp. In contrast, ovarian tissues from all 6 female broodstock were RT-PCR negative and only weakly $(-/+$ or + ) positive following nested PCR.

\section{Detection of GAV in eggs and nauplii from wild spawnings by RT-nested PCR}

RT-nested PCR was used to detect GAV in eggs and nauplii collected from spawnings of 5 wild-fertilized female Penaeus monodon broodstock from north-east Queensland. Although non-specific RT-PCR products were amplified from some samples, GAV-specific nested PCR products (317 bp) were amplified from all 5 egg samples and from 3 of the 5 nauplii samples (Fig. 3). Of the 3 spawnings that produced nested PCRpositive eggs and nauplii, 2 gave similar product yields while the third gave a slightly lower product yield from nauplii.

\section{RT-nested PCR and sequence analysis of GAV in broodstock and progeny of individual matings}

Penaeus monodon broodstock used in individual matings were collected at 4 locations from Townsville to Cairns in north-east Queensland. Spermatophores of males from each location were used to impregnate females collected from a different location. Progeny from individual matings were segregated and reared, where possible, to postlarval stage PL5. Spawning and egg hatching rates were generally poor and some difficulties were experienced in rearing all progeny. RTnested PCR was used to detect GAV in the parents and various life stages. The results of RT-nested PCR tests using the GAV5/6 and GAV1/2 primer pairs (Cowley et al. 2000b) and RNA from the parents and progeny of 10 successful matings are shown in Table 2. Lymphoid organs of 6 male and 8 female broodstock were GAVpositive in the RT-PCR. However, all were positive following nested PCR. Of the 10 fertilized egg samples, 8 
Table 1. Penaeus monodon. GAV RT-PCR and nested PCR (nPCR) product yields with lymphoid organ, spermatophore and ovarian tissue of adults reared in captivity for > 12 mo. PCR: 618 bp RT-PCR using primer pair GAV5/GAV6; nPCR: 317 bp-nested PCR using primer pair GAV1/GAV2. The relative amount of PCR product from strongly positive to negative was scored,,,,$++++++++++-/+,-$

\begin{tabular}{|llllllll|}
\hline \multirow{2}{*}{ Broodstock } & Sex & \multicolumn{2}{c}{ Lymphoid organ } & \multicolumn{2}{c|}{ Spermatophore } & \multicolumn{2}{c|}{ Ovarian tissue } \\
& & PCR & nPCR & PCR & nPCR & PCR & nPCR \\
\hline 1 & M & - & +++ & ++++ & ++++ & & \\
2 & M & +++ & ++++ & ++++ & ++++ & & \\
3 & M & - & ++ & +++ & ++++ & & \\
4 & M & - & $-l+$ & +++ & ++++ & & \\
5 & F & - & $-l+$ & & & - & $-1+$ \\
6 & F & - & ++ & & & - & + \\
7 & F & + & ++++ & & & - & + \\
8 & F & - & +++ & & & - & + \\
9 & F & - & +++ & & & - & + \\
10 & F & - & ++ & & & - & $-/+$ \\
\hline
\end{tabular}

the 295 bp region bounded by the nested PCR primer pair GAV1/GAV2, nested PCR products generated from the alternative region downstream of ORF1b were used for sequence comparisons.

RT-nested PCR amplicons (556 bp) generated using primer pair GAV175/ GAV176 and RNA isolated from parental lymphoid organs and progeny eggs of 6 selected matings were sequenced in both directions (Fig. 4). GAV present in the parents of Mating no. 2 possessed 15 nucleotide variations, 7 of which included changes scored on the basis that the female appeared to contain mixed GAV genotypes that resulted in similar amounts of 2 nucleotides (i.e. $\mathrm{Y}=\mathrm{C} / \mathrm{T}$ and $\mathrm{M}=\mathrm{A} / \mathrm{C}$ ).

were GAV-positive in the nested PCR. Only 1 each of the 10 nauplii and 9 available protozoea samples were GAV-positive in the nested PCR. Of 7 available PL5 samples, 3 were GAV-positive in the nested PCR. However, due to poor survival rates, there were only 2 individual postlarvae in 4 of the PL5 samples and it should be noted that these corresponded to the samples that tested PCR-negative.

RT-nested PCR was also conducted using alternative primers targeting a GAV gene open reading frame downstream of the ORF1ab gene (Table 3). In comparison to the data reported above, RT-PCR product yields for lymphoid organ RNA from 3 males were significantly lower. For the females, RT-PCR yields were significantly lower in 2 cases and higher in 2 other cases. With the exception of 1 male lymphoid organ, nested PCR product yields were comparable. As in the method above (see Table 2), all 10 egg samples were RT-PCR-negative while the same 8 egg samples were GAV-positive by nested PCR. The same 3 of 7 PL5 samples were nested PCR-positive for GAV in both tests.

\section{Sequence comparison of GAV in broodstock and progeny from artificial matings}

Small variations in the genotype of GAV isolates in individual shrimp were used to determine the parental origin of virus detected in progeny of individual artificial matings. Comparisons of RT-PCR amplicons (577 bp) generated using primer pair GAV5/GAV6 identified little $(<1 \%)$ nucleotide sequence variation between selected male and female broodstock from the different locations in north-east Queensland (data not shown). As little or no variation was observed in
Although the primary sequence of GAV detected in eggs from this mating matched the female, the presence of an $\mathrm{R}(\mathrm{A} / \mathrm{G})$ and $\mathrm{Y}(\mathrm{C} / \mathrm{T})$ at 2 variable positions also suggested the presence of some virus from the male. Eleven nucleotide variations, 3 of which generated amino acid changes, were detected between the GAV sequences amplified from the parents used in Mating no. 3. The GAV sequence amplified from eggs was identical to that of the female. In Mating no. 4, there were 13 nucleotide variations between GAV present in each parent, 2 of which included changes scored on the basis that the male appeared to contain mixed virus genotypes that resulted in similar amounts of 2 nucleotides (i.e. $\mathrm{Y}=\mathrm{C} / \mathrm{T}$ and $\mathrm{R}=\mathrm{A} / \mathrm{G}$ ). As in Mating no. 3, the GAV sequence amplified from eggs was identical to that in the female. GAV amplified from both parents and the eggs of Mating no. 8 possessed identical sequences, and thus the parental origin could not be determined. GAV amplified from the parents of Mating no. 9 possessed 13 nucleotide variations, 1 of sequence detected in eggs of this mating appeared to be a mixture of viruses from both the male and female shrimp, with a combination of 2 nucleotides (i.e. $\mathrm{Y}=$ $\mathrm{C} / \mathrm{T}, \mathrm{R}=\mathrm{G} / \mathrm{A}$ and $\mathrm{K}=\mathrm{G} / \mathrm{T}$ ) in relatively equal amounts at most divergent positions. It should be noted that while lymphoid organ RNA from the male used in this mating was positive in the 1-step RT-PCR, the 2-step nested PCR was required to detect GAV in the female. GAV present in the parents of Mating no. 10 varied at only 2 nucleotide positions and the sequence of GAV associated with eggs was the same as that in the male. The parents of this mating originated from Cairns and Innisfail, and the sequence of GAV present in shrimp from these locations were generally more closely related than GAV in shrimp originating from which generated an amino acid change. The GAV 
Table 2. Penaeus monodon. RT-PCR (GAV5/GAV6) and nested-PCR (GAV1/GAV2) data with parental lymphoid organ and progeny RNA from 10 individual matings of broodstock captured from different locations. CNS: Cairns; INF: Innisfail; ING: Ingham; TSV: Townsville; nd: no data; nt: not tested. Symbols as in Table 1

\begin{tabular}{|c|c|c|c|c|c|c|c|c|c|c|c|c|c|c|}
\hline \multirow{2}{*}{$\begin{array}{l}\text { Mating } \\
\text { no. }\end{array}$} & \multicolumn{3}{|c|}{ Male } & \multicolumn{3}{|c|}{ Female } & \multicolumn{2}{|c|}{ Eggs } & \multicolumn{2}{|c|}{ Nauplii } & \multicolumn{2}{|c|}{ Protozoea } & \multicolumn{2}{|c|}{ PL5 } \\
\hline & Area & PCR & nPCR & Area & PCR & nPCR & PCR & nPCR & PCR & nPCR & PCR & nPCR & PCR & nPCR \\
\hline 1 & TSV & - & +++ & CNS & +++ & $\mathrm{nt}$ & - & - & - & - & - & - & - & - \\
\hline 2 & TSV & ++++ & +++ & INF & +++ & $\mathrm{nt}$ & - & ++ & - & ++ & - & - & - & +++ \\
\hline 3 & TSV & - & +++ & CNS & ++++ & nt & - & +++ & - & - & - & - & - & - \\
\hline 4 & TSV & - & ++ & CNS & - & ++ & - & ++ & - & - & - & - & - & - \\
\hline 5 & INF & ++++ & +++ & CNS & - & ++ & - & - & - & - & - & - & - & +++ \\
\hline 6 & INF & ++++ & +++ & ING & ++++ & nt & - & ++ & - & - & - & - & - & +++ \\
\hline 7 & TSV & - & $++^{\mathrm{a}}$ & CNS & +++ & $\mathrm{nt}$ & - & ++ & - & - & - & - & nd & nd \\
\hline 8 & TSV & ++++ & +++ & ING & +++ & $\mathrm{nt}$ & - & ++ & - & - & - & ++ & - & - \\
\hline 9 & TSV & +++ & +++ & INF & ++++ & nt & - & +++ & - & - & nd & nd & nd & nd \\
\hline 10 & INF & ++++ & +++ & CNS & ++++ & nt & - & ++ & - & - & - & - & nd & nd \\
\hline
\end{tabular}

Table 3. Penaeus monodon. RT-PCR (GAV69/GAV121) and nested-PCR (GAV175/GAV176) data with parental lymphoid organ and progeny RNA from individual matings of broodstock captured from different locations. Abbreviations as in Table 2; symbols as in Table 1

\begin{tabular}{|c|c|c|c|c|c|c|c|c|c|c|c|}
\hline \multirow{2}{*}{$\begin{array}{l}\text { Mating } \\
\text { no. }\end{array}$} & \multicolumn{3}{|c|}{ Male } & \multicolumn{3}{|c|}{ Female } & \multicolumn{2}{|c|}{ Eggs } & \multicolumn{2}{|c|}{ PL5 } & \multirow[t]{2}{*}{ GAV origin in eggs } \\
\hline & Area & PCR & $\mathrm{nPCR}$ & Area & PCR & nPCR & PCR & $\mathrm{nPCR}$ & PCR & $\mathrm{nPCR}$ & \\
\hline 1 & TSV & - & +++ & CNS & - & +++ & - & - & - & - & \\
\hline 2 & TSV & + & ++++ & INF & + & ++++ & - & ++++ & - & ++ & Female and male \\
\hline 3 & TSV & - & ++++ & CNS & ++ & ++++ & - & ++++ & - & - & Female \\
\hline 4 & TSV & - & ++++ & CNS & + & ++++ & - & +++ & - & - & Female \\
\hline 5 & INF & + & ++++ & CNS & +++ & ++++ & - & - & - & +++ & \\
\hline 6 & INF & +++ & ++++ & ING & ++++ & ++++ & - & +++ & - & +++ & \\
\hline 7 & TSV & - & +++ & CNS & ++++ & ++++ & - & +++ & nd & nd & \\
\hline 8 & TSV & - & +++ & ING & ++++ & ++++ & - & +++ & - & - & Female and/or male \\
\hline 9 & TSV & ++ & ++++ & INF & - & ++++ & - & ++++ & nd & nd & Female and male \\
\hline 10 & INF & ++++ & ++++ & CNS & ++++ & ++++ & - & ++++ & nd & nd & Male \\
\hline
\end{tabular}

Townsville, which is geographically more distant. Moreover, it may be relevant that the GAV load identified in the male used in this mating (see Table 3) was significantly higher than in the other 5 males analyzed. The parental origin deduced for GAV associated with eggs of the 6 matings examined is summarized in Table 3 .

\section{DISCUSSION}

In this paper, we present molecular evidence for vertical transmission of gill-associated virus (GAV) from chronically infected wild Penaeus monodon broodstock captured from the north-east Queensland region of Australia. Chronic GAV infection is common in this broodstock population and in farmed P. monodon in Australia (Spann et al. 1997, Cowley et al. 2000b, Walker et al. 2001). RT-nested PCR was used to detect GAV in the reproductive tissues of overtly healthy broodstock. However, the product yields amplified from spermatophores and mature ovaries suggest that virus levels are generally low in these tissues. In contrast, high product yields were amplified by 1-step RTPCR using RNA from spermatophores of moribund male broodstock reared in captivity for $>12$ mo, suggesting the presence of high levels of GAV. In these shrimp, the spermatophore RT-PCR product yields were also significantly greater than those amplified from the lymphoid organ, which we have previously identified as the primary site of GAV replication in chronically infected P. monodon (Spann et al. 1995). It should be noted, however, that the spermatophores of these shrimp displayed an abnormal 'shrivelled' appearance (M. R. Hall pers. obs.). Moreover, in 1 of 3 shrimp examined by TEM, mature GAV virions were detected in the seminal fluid but not in sperm cells. The process by which high GAV loads accumulated in the spermatophores of these captive-reared P. monodon is not known. However, the shrimp were moribund at the time of sampling and were from a group experiencing frequent mortalities. This was suggestive 


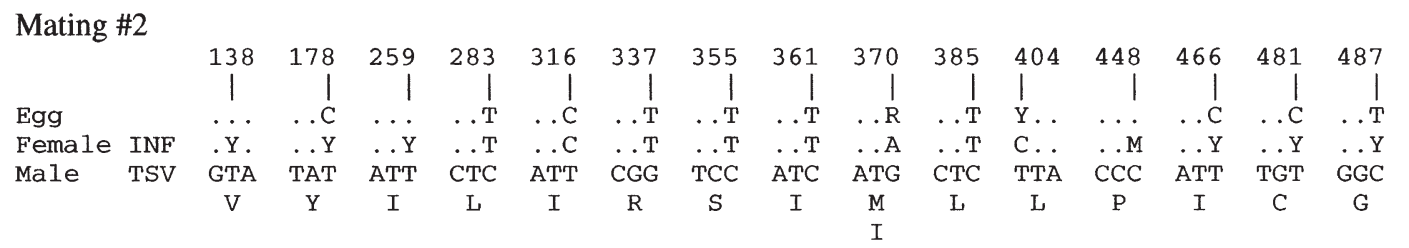

Mating \#3

\begin{tabular}{|c|c|c|c|c|c|c|c|c|c|c|c|c|}
\hline & & 109 & 137 & 158 & 196 & 259 & 280 & 410 & 448 & 466 & 481 & 487 \\
\hline gg & & . . C & G. & A. & $\ldots C$ & $\ldots C$ & $\ldots \mathrm{T}$ & C. & . C & $\ldots T$ &. $\mathrm{~T}$ & . C \\
\hline Female & CNS & $\ldots \mathrm{C}$ & G. . & A. & $\ldots \mathrm{C}$ & $\ldots \mathrm{C}$ & $\ldots \mathrm{T}$ & C. & $\ldots \mathrm{C}$ & $\ldots T$ & $\ldots \mathrm{T}$ & $\mathrm{C}$ \\
\hline Male & TSV & $\mathrm{ATT}$ & СТA & GTC & ACT & ATT & CAC & TCC & TTT & ATC & TGC & GT \\
\hline & & I & $\mathrm{L}$ & V & $\mathrm{T}$ & I & $\mathrm{H}$ & s & $\mathrm{F}$ & I & C & \\
\hline & & & $\mathrm{V}$ & I & & & & & & & & \\
\hline
\end{tabular}

\section{Mating \#4}

\begin{tabular}{|c|c|c|c|c|c|c|c|c|c|c|c|c|c|c|}
\hline Drate & & & & & & & & & & & & & & \\
\hline & & $\begin{array}{r}259 \\
1\end{array}$ & 280 & $\begin{array}{r}283 \\
1\end{array}$ & $\begin{array}{r}316 \\
1\end{array}$ & 337 & 355 & $\begin{array}{r}361 \\
\mid\end{array}$ & 370 & $\begin{array}{r}385 \\
1\end{array}$ & $\left.\right|^{404}$ & 466 & 481 & 487 \\
\hline Egg & & $\ldots \mathrm{C}$ & $\ldots Y$ & $\ldots \mathrm{C}$ & $\ldots \mathrm{T}$ & $\ldots G$ & C & . C & $\ldots G$ & $\ldots C$ & T. . & $\ldots \mathrm{T}$ & $\ldots \mathrm{T}$ & . . C \\
\hline Female & CNS & $\ldots \mathrm{C}$ & $\ldots T$ & $\ldots \mathrm{C}$ & $\ldots \mathrm{T}$ & $\ldots G$ & . C & $\ldots \mathrm{C}$ & $\ldots G$ & $\ldots \mathrm{C}$ & T. & $\ldots \mathrm{T}$ & $\ldots \mathrm{T}$ & $\ldots \mathrm{C}$ \\
\hline Male & TSV & ATT & CAT & СТT & ATC & CGT & TCY & ATT & ATR & CTT & СTA & ATC & TGC & GGT \\
\hline & & I & $\mathrm{H}$ & $\mathrm{L}$ & I & $\mathrm{R}$ & 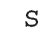 & I & M & L & $\mathrm{L}$ & I & $\mathrm{C}$ & G \\
\hline
\end{tabular}

Mating \#9

\begin{tabular}{|c|c|c|c|c|c|c|c|c|c|c|c|c|c|c|}
\hline & & & & & & & & & & & & & & \\
\hline & & 259 & 283 & 316 & 337 & 355 & 361 & 370 & 385 & 404 & 448 & 466 & 481 & 487 \\
\hline Egg & & & $\ldots Y$ & $\ldots \mathrm{Y}$ & $\ldots \mathrm{K}$ & $\ldots Y$ & $\ldots \mathrm{Y}$ & $\ldots \mathrm{R}$ & $\ldots Y$ & Y. . & $\ldots \mathrm{Y}$ & $\ldots \mathrm{Y}$ & $\ldots \mathrm{Y}$ & $\ldots \mathrm{Y}$ \\
\hline Female & INF & $\ldots C$ & $\ldots \mathrm{T}$ & $\ldots \mathrm{C}$ & $\ldots \mathrm{T}$ & $\ldots \mathrm{T}$ & $\ldots \mathrm{T}$ & $\ldots A$ & $\ldots \mathrm{T}$ & C. . & $\ldots \mathrm{T}$ & $\ldots \mathrm{C}$ & $\ldots \mathrm{C}$ & $\ldots \mathrm{T}$ \\
\hline Male & TSV & ATT & СтC & ATT & CGG & TCC & ATC & ATG & СTC & TTA & TTC & ATT & TGT & GGC \\
\hline & & I & T & $T$ & $\mathrm{R}$ & $\mathrm{S}$ & I & M & $\mathrm{L}$ & $\mathrm{L}$ & $\mathrm{F}$ & I & C & G \\
\hline
\end{tabular}

\section{Mating \#10}

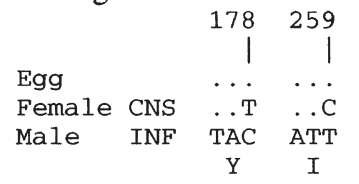

Fig. 4. Penaeus monodon. Sequence comparison of RTnested PCR amplicons generated using total RNA either from the lymphoid organs of parental broodstock or from progeny eggs from 5 individual matings. GAV sequences (556 bp) encompassed by the primer pair GAV175/GAV176 were determined on both DNA strands and compared. Only those codons that displayed nucleotide variations are shown. The nucleotide (shown as DNA) and amino acid sequences of the GAV genotype in the male shrimp are shown in full. Nucleotide differences (relative positions are indicated) of GAV amplified from the female shrimp and from eggs are shown above the GAV sequence in the male (nucleotide designations $\mathrm{Y}=\mathrm{C} / \mathrm{T}, \mathrm{R}=\mathrm{A} / \mathrm{G}, \mathrm{M}=\mathrm{A} / \mathrm{C}, \mathrm{K}=$ $\mathrm{T} / \mathrm{G})$. Amino acid changes resulting from nucleotide variations are shown below that of GAV in the male of overt GAV-induced disease in these shrimp, possibly triggered by the stress of long-term captivity. Unfortunately samples were not available for histological and TEM confirmation of acute GAV infection. Further research is required to determine whether GAV replicates in male and female reproductive tissues, the process by which mature virions can accumulate in seminal fluid, and the relationship between the level of GAV infection and establishment of an acute disease state.

GAV was detected in association with eggs and nauplii of spawnings of wild-fertilized Penaeus monodon broodstock collected from north-east Queensland. RTnested PCR data obtained with these and progeny from other matings indicated that the virus can generally be detected using eggs, while nauplii and protozoea life stages are more often PCR-negative. This suggests that GAV is likely to be associated with the egg surface, that the majority of the virus is lost upon nauplii hatching, and that infection levels in the protozoea life stage remain low. The lymphoid organ is known to be the primary site of GAV replication in juvenile and sub-adult shrimp infected asymptomatically (Spann et al. 1995). Due to the early stage of infection, and possibly the early developmental stage of the lymphoid organ itself, it is not unexpected that GAV levels in larval life stages may be below the detection limit of RT-nested PCR. In contrast, testing of individual or groups of P. monodon postlarvae (PL5 to PL15) suggests that GAV loads in postlarval stages can increase to levels sufficient, in some cases, to be detected by the less sensitive 1-step RT-PCR (Walker et al. 2001). It is extremely difficult to confirm the presence of GAV in the lymphoid organs of larvae and postlarvae by light microscopy or TEM. However, spheroids and GAV nucleocapsids/virions were universally observed in the lymphoid organs of $\sim 1.2 \mathrm{~g}$ juvenile $P$. monodon reared under contained laboratory conditions from hatchery PL6 and PL20 stocks. This confirmed that some, if not all, of these postlarvae were harbouring GAV. As individual postlarvae were not grown in isolation, however, we cannot discount 
that some infections may have arisen through cannibalism or water-borne transmission during the limited grow-out. Although such horizontal transmission routes may contribute to early life stage infections, better understanding of the mechanisms by which eggs, nauplii or later larval stages become infected following spawning will assist in the establishment of hatchery practices designed to limit vertical transmission of GAV. If GAV is associated with the egg surface, it may be possible to disinfect or wash eggs to inactivate or remove contaminating virus.

Screening by RT-nested PCR has indicated that the prevalence of asymptomatic chronic GAV infection in wild-captured broodstock in the Cairns to Townsville region in north-east Queensland approaches 100\% (Cowley et al. 2000b, Walker et al. 2001). Broodstock from this region supply hatcheries that distribute postlarvae to farms throughout Australia. Thus, vertical transmission will promote translocation of GAV and the potential infection of wild Penaeus monodon in the vicinity of farms via contaminated water or escape of virus-infected shrimp. The high infection prevalence in wild P. monodon from north-east Queensland also suggests that hatchery screening of broodstock will not be practical unless it can be demonstrated that there is a correlation between low GAV levels in broodstock and/or postlarvae and reduced risk of disease occurring on farms. Data obtained with other shrimp viruses suggest that such studies are warranted. For example, associations between the levels of white spot syndrome virus (WSSV) detected by PCR in the receptaculum seminis of Mapsupenaeus japonicus following spawning and the occurrence of disease in postlarvae has resulted in an egg selection criterion based on PCR screening procedures (Mushiake et al. 1999). Similarly, PCR and in situ hybridization have been used to identify WSSV levels in the testis, spermatophore and ovaries of $P$. monodon broodstock (Lo et al. 1997). This has allowed formulation of rational PCR screening practices to limit or avoid the production of heavily infected progeny in hatcheries and the risk of WSSV disease on farms.

Sequence analysis of PCR amplicons from parental shrimp and eggs of individual artificial matings suggests that GAV associated with progeny can be contributed from both the male and female parents. The female appears to be the primary source of GAV associated with eggs. However, in one case (see Table 3, Mating no. 9) where the female appeared to harbour a low-level infection compared to the male, a mixed genotype comprising GAV sequences from both parents was identified in virus amplified from eggs. In another case (Table 3, Mating no. 10), where both the male and female appeared heavily infected based on RT-PCR detection of GAV in the lymphoid organ, the virus genotype identified in eggs was the same as that in the male. It appears, therefore, that infection levels in parental shrimp can influence the primary source of GAV associated with eggs. However, experimental matings between uninfected and GAV-infected broodstock should give a much clearer picture of the role of each parent in transmitting virus during spawning and of the process by which this occurs. We are currently using RT-nested PCR to screen wild Penaeus monodon sourced from different locations (Walker et al. 2001) in an attempt to locate GAV-free populations for this purpose and as the nucleus of domestication and selective breeding programs.

GAV represents a (+) ssRNA virus provisionally classified as the first invertebrate virus and the type species of a new genus, Okavirus, within the Nidovirales (Cowley et al. 2000a, 2001). Genetic recombination in the vertebrate coronaviruses (Makino et al. 1986) and arteriviruses (Li et al. 1999) can occur at high frequency during co-infections and can contribute significantly to genetic and phenotypic variability among these nidoviruses. The contribution of GAV from both male and female Penaeus monodon during spawning may establish dual infection states in progeny that provide opportunities to generate genetic recombinants. In this regard, GAV and YHV possess sufficient genetic relatedness to be considered as geographic topotypes (Cowley et al. 1999). It is possible, therefore, that dual infection of either progeny or adult shrimp with GAV and YHV could result in recombination events generating modified viruses with enhanced virulence. The potential for genetic recombination has significant ramifications for the translocation of $P$. monodon broodstock harbouring either GAV or YHV between sites in the Asia-Pacific region.

There have been several reports detailing the range of shrimp species that are susceptible to disease following experimental infection with YHV (Lu et al. 1994, Lightner et al. 1998) and GAV (Spann et al. 2000), but few examining susceptibility following likely natural routes of horizontal transmission (Flegel et al. 1995). Even less experimental data is available on the vertical transmission of these viruses from broodstock to progeny. TEM screening of Penaeus monodon broodstock in Thailand has suggested that the prevalence of YHV is low and, therefore, that vertical transmission is unlikely to contribute significantly to the occurrence of infections and disease on farms (Flegel et al. 1995, 1997a,b). However, this may need reconsideration as more recent screening of broodstock using RT-nested PCR (Walker et al. 2001) suggests that the prevalence of YHV infections may be significantly higher than originally identified by TEM. Taken together with the data presented here, the high prevalence of chronic GAV infection in P. monodon brood- 
stock from north-east Queensland (Cowley et al. 2000b) and farmed shrimp produced from these broodstock (Spann et al. 1995, Spann 1997) strongly suggests that this is perpetuated primarily by vertical transmission in the wild and in hatcheries.

Acknowledgements. The authors wish to thank Gold Coast Marine Aquaculture and Grasstree prawn hatchery for supplying shrimp and Matt Kenway, Matthew Salmon and Don Booth for assistance in rearing and sampling shrimp.

\section{LITERATURE CITED}

Boonyaratpalin S, Supamattaya K, Kasornchandra J, Direkbusaracom S, Aekpanithanpong U, Chantanachookin C (1993) Non-occluded baculo-like virus, the causative agent of yellow-head disease in the black tiger shrimp (Penaeus monodon). Fish Pathol 28:103-109

Chantanachookin C, Boonyaratpalin S, Kasornchandra J, Sataporn D, Ekpanithanpong U, Supamataya K, Sriurairatana S, Flegel TW (1993) Histology and ultrastructure reveal a new granulosis-like virus in Penaeus monodon affected by yellow-head disease. Dis Aquat Org $17: 145-157$

Cowley JA, Dimmock CM, Wongteerasupaya C, Boonsaeng V, Panyim S, Walker PJ (1999) Yellow head virus from Thailand and gill-associated virus from Australia are closely related but distinct viruses. Dis Aquat Org 36: 153-157

Cowley JA, Dimmock CM, Spann KM, Walker PJ (2000a) Gill-associated virus of Penaeus monodon prawns: an invertebrate virus with ORF1a and ORF1b genes related to arteri- and coronaviruses. J Gen Virol 81:1473-1484

Cowley JA, Dimmock CM, Spann KM, Walker PJ (2000b) Detection of Australian gill-associated virus (GAV) and lymphoid organ virus (LOV) of Penaeus monodon by RTnested PCR. Dis Aquat Org 39:159-167

Cowley JA, Dimmock CM, Spann KM, Walker PJ (2001) Gillassociated virus of Penaeus monodon prawns: molecular evidence for the first invertebrate nidovirus. Adv Exp Med Biol 494:43-48

Flegel TW, Sriurairatana S, Wongteerasupaya C, Boonsaeng V, Panyim S, Withyachumnarnjul B (1995) Progress in characterization and control of yellow-head virus of $P e$ naeus monodon. In: Browdy CL, Hopkins JS (eds) Shrimp biotechnology in Thailand. National Center for Genetic Engineering and Biotechnology, Bangkok, p 76-83

Flegel TW, Sriurairatana S, Morrison DJ, Waiyakrutha N (1997a) Penaeus monodon captured broodstock surveyed for yellow-head virus and other pathogens by electron microscopy. In: Flegel TW, Menasveta P, Paisarnrat S (eds) Shrimp biotechnology in Thailand. National Center for Genetic Engineering and Biotechnology, Bangkok, p $37-43$

Editorial responsibility: Timothy Flegel, Bangkok, Thailand
Flegel TW, Boonyaratpalin S, Withyachumnarnkul B (1997b) Progress in research on yellow-head virus and white-spot virus in Thailand. In Flegel TW, MacRae IH (eds) Diseases in Asian Aquaculture. III. Fish Health Section, Asian Fisheries Society, Manila, p 285-295

Li K, Chen Z, Plagemann P (1999) High-frequency homologous genetic recombination of an arterivirus, lactate dehydrogenase-elevating virus, in mice and evolution of neuropathogenic variants. Virology 258:73-83

Lightner DV, Hasson KW, White BL, Redman RM (1998) Experimental infection of western hemisphere penaeid shrimp with Asian white spot syndrome virus and Asian yellow head virus. J Aquat Animal Health 10:271-281

Lo CF, Ho CH, Chen CH, Liu KF and 9 others (1997) Detection and tissue tropism of white spot syndrome baculovirus (WSBV) in captured brooders of Penaeus monodon with a special emphasis on reproductive organs. Dis Aquat Org 30:53-72

Lu Y, Tapay LM, Brock JA, Loh PC (1994) Infection of the yellow head baculo-like virus (YBV) in two species of penaeid shrimp, Penaeus stylirostris (Stimpson) and Penaeus vannamei (Boone). J Fish Dis 17:649-656

Makino S, Keck JG, Stohlman SA, Lai MM (1986) Highfrequency RNA recombination of murine coronaviruses. J Virol 57:729-737

Mushiake K, Shimizu K, Satoh J, Mori KI, Arimoto M, Ohsumi SI, Imaizumi K (1999) Control of penaeid acute viremia (PAV) in Penaeus japonicus: selection of eggs based on the PCR detection of the causative virus (PRDV) from receptaculum seminis of spawned broodstock. Fish Pathol 34:203-207

Spann KM (1997) Four viruses of wild and cultured penaeid prawns from Queensland, Australia. PhD thesis, University of Queensland, Brisbane

Spann KM, Vickers JE, Lester RJG (1995) Lymphoid organ virus of Penaeus monodon from Australia. Dis Aquat Org 23:127-134

Spann KM, Cowley JA, Walker PJ, Lester RJG (1997) A yellow-head-like virus from Penaeus monodon cultured in Australia. Dis Aquat Org 31:169-179

Spann, KM, Donaldson RA, Cowley JA, Walker PJ (2000) Differences in the susceptibility of some penaeid prawn species to gill-associated virus (GAV) infection. Dis Aquat Org 42:221-225

Walker PJ, Cowley JA, Spann KM, Hodgson RAJ, Hall MR, Withyachumnarnkul B (2001) Yellow head complex viruses: transmission cycles and topographical distribution in the Asia-Pacific region. In: Browdy CL, Jory DE (eds) The new wave: Proceedings of the Special Session on Sustainable Shrimp Culture, Aquaculture 2001. World Aquaculture Society, Baton Rouge, LA, p 227-237

Wang YC, Chang PS (2000) Yellow head virus infection in the giant tiger prawn Penaeus monodon cultured in Taiwan. Fish Pathol 35:1-10

Wongteerasupaya C, Sriurairatana S, Vickers JE, Akrajamorn A and 5 others (1995) Yellow-head virus of Penaeus monodon is an RNA virus. Dis Aquat Org 22:45-50

Submitted: July 27, 2001; Accepted: February 11, 2002

Proofs received from author(s): July 2, 2002 